DOI: https://doi.org/10.32839/2304-5809/2021-11-99-81

УДК 369.041

Західна О.P., Довгий А.І., Карлик Н.О.

Львівський національний університет імені Івана Франка

\title{
СИСТЕМА СОЦІАЛЬНОГО ЗАХИСТУ НАСЕЛЕННЯ В УКРАЇНІ
}

Анотація. Досліджено теоретичні питання функціонування системи соціального захисту в Україні, наведена структура системи соціального захисту населення в Україні та охарактеризовано основні складові системи соціального захисту. Проведено аналіз динаміки видатків зведеного бюджету на соціальний захист та соціальне забезпечення населення протягом 2016-2020 pр. Здійснено оцінку основних соціальноекономічних індикаторів рівня життя населення як наслідок впливу функціонування системи соціального захисту. Окреслено напрями удосконалення системи соціального захисту в Україні.

Ключові слова: соціальний захист, соціальне забезпечення, соціальні стандарти, соціальні гарантії, рівень життя.

Zakhidna Oksana, Dowhyj Andrij, Karlyk Nazarij

Lviv Ivan Franko National University

\section{SYSTEM OF SOCIAL PROTECTION OF THE POPULATION IN UKRAINE}

Summary. Theoretical issues of the functioning of the social protection system in Ukraine are studied, the structure of the social protection system in Ukraine is given and the main components of the social protection system are characterized: social insurance, social assistance, social justice (social solidarity). The content of the concept of social protection and social security from the macro- and microeconomic point of view is revealed. The main goals of social protection are defined. The main functions of social protection are given. The characteristics of such basic structural elements of the social protection system as social guarantees are given; social standards; Social Insurance; social assistance; social services. An analysis of the dynamics of the consolidated budget expenditures on social protection and social security of the population during 2016-2020. The dynamics of the share of consolidated budget expenditures on social protection and social security as a percentage of total expenditures and as a percentage of gross domestic product was also analyzed. An analysis of the dynamics of expenditures of the Consolidated Budget of Ukraine for social protection and social security according to the functional classification of expenditures and budget lending during 2016-2020. It is emphasized that in Ukraine there is no single legislative document that would regulate all aspects of social protection in the country, there is no official definition of "social protection", there is also no state strategy for social protection in Ukraine. The directions of improvement of the social protection system in Ukraine are outlined. It is determined that the goals are extremely important, the achievement of which will allow to update and optimize the system of social protection of Ukraine in accordance with modern challenges: 1 . Transformation of the strategy of the social protection system - the transition to creating opportunities instead of overcoming the consequences. The priority should be not only social protection of the population, but also active policies aimed at reducing unemployment and increasing the share of wages in the income structure of the population. 2. Improving the regulatory framework governing general issues of social protection. The priority of updating the legislation should be to reform the system of benefits and other types of social benefits, its unification and strengthening targeted state social assistance. The outlined measures will help increase the efficiency of the social protection system.

Keywords: social protection, social security, social standards, social guarantees, standard of living.

$\Pi$ остановка проблеми. Згідно зі ст.1 Конституції України, Україна є суверенна і незалежна, демократична, соціальна, правова держава [1]. Це, перш за все, означає наявність державного пріоритету щодо забезпечення соціальних та економічних прав громадян. Сощіальний захист - це система суспільно-економічних заходів, спрямованих на матеріальне забезпечення населення від соціальних ризиків (хвороба, інвалідність, старість, втрата годувальника, безробіття, нещасний випадок на виробництві тощо). Проте, на думку експертів у досліджуваній сфрері, функціонування системи соціального захисту в Україні є не завжди ефективним, i, як наслідок, не у повній мірі сприяе покращенню рівня життя населення.

Аналіз останніх досліджень і публікацій. Питанням, пов'язаним з проблемами та розвитком системи соціального захисту, присвячені праці багатьох вітчизняних дослідників: Н. Абакумової, Н. Борецької, В. Гейця, В. Гетьмана, К. Дідківської, О. Длугопольського, Е. Лібанової, I. Рудкевич, I. Сироти, А. Сіленко, А. Халецької,
П. Шевчука, Л. Черенько та ін. Однак, сучасний стан системи соціального захисту та його вплив на рівень життя населення України засвідчує необхідність детальнішого аналізу й окреслення напрямів удосконалення вітчизняної системи соціального захисту.

Виділення не вирішених раніше частин загальної проблеми. В Україні, на жаль, немає єдиного законодавчого документу, який би регулював усі аспекти сощіального захисту в державі, також відсутне офіційне визначення поняття «соціальний захист». Відсутня також і державна стратегія соціального захисту населення в Україні. Незважаючи на численні публікації 3 досліджуваної теми, окремі питання не отримали достатньої уваги. На наш погляд, актуальною є проблема визначення вектору структурних трансформацій системи соціального захисту 3 метою реального підвищення рівня життя населення в Україні.

Мета статті. Головною метою цієї роботи є характеристика структури системи соціального захисту населення в Україні, аналіз та ощінка 
впливу системи соціального захисту на рівень життя населення в Україні.

Виклад основного матеріалу. 3 макроекономічної точки зору соціальне забезпечення - це система управління соціальними ризиками з метою компенсації шкоди, зниження або запобігання їх дії на процес розширеного відтворення населення. Як соціально-економічна категорія соціальне забезпечення є відносинами щодо перерозподілу національного доходу 3 метою забезпечення встановлених соціальних стандартів життя для кожної людини в умовах дії соціальних ризиків.

Державний соціальний захист у його широкому значенні розуміється як державна політика і цілеспрямовані дії, а також відповідна ресурсна база, передусім - кошти держави і суспільства. Саме вони забезпечують особі, соціальній групі, суспільній верстві, населенню країни загалом комплексне, усебічне розв'язання різних проблем, зумовлених соціальними ризиками, котрі можуть призвести (чи вже призвели) до повної або часткової втрати зазначеними суб'єктами можливості реалізації конституційних прав, гарантій, свобод і законних інтересів, економічної самостійності, реалізації принципів соціальної справедливості, а також суспільного добробуту [10].

У вузькому розумінні державний соціальний захист $є$ комплексом заходів та відповідних конкретних механізмів, що використовуе держава 3 метою акумуляції необхідних ресурсів і запровадження ефрективних механізмів підтримки реальних доходів та суспільно допустимого рівня споживання соціально вразливих груп і верств населення, передусім непрацездатних, непрацюючих, а в окремих (особливих, ризикових) ситуаціях - й інших економічно вразливих верств [10]. uiлi:

Соціальний захист в Україні має такі основні

- забезпечення рівня життя непрацездатного населення не нижче прожиткового мінімуму встановленого державою;

- протидія соціальному напруженню в суспільстві, що може бути зумовлене майновою, етнічною, релігійною чи іншою нерівністю.

Основними ббункціяли соціального захисту в Україні є такі:

- реабілітаційна, покликана пом'якшувати наслідки бідності та інших негативних соціальних явищ;

- превентивна, яка полягає в запобіганні виникненню негативних соціальних явищ.

Соціальний захист в Україні мае такі складові частини:

- Соціальне страхування - захист громадян від соціальних ризиків, що впливають на їх працездатність: хвороба, каліцтво, старість, та інші випадки, передбачені законом;

- Соціальна дополога - різні види соціальних виплат, дотацій, пільг, субсидій, що надаються особам, які потребують соціального захисту;

- Соціальна справедливість (соціальна солідарність) - компенсація впливу непередбачуваних негативних явищ, таких як техногенні катастрофи чи природні стихійні лиха.

Аналіз різноманітних підходів і поглядів дослідників на структуру державної системи соціального захисту населення дозволяє зробити висновок про те, що їі основними структурними елементами є:

- соціальні гарантії. Основними соціальними гарантіями є: мінімальний розмір заробітної плати; мінімальний розмір пенсії за віком; неоподатковуваний мінімум доходів громадян; розміри державної соціальної допомоги та інших соціальних виплат;

- соціальні стандарти. Базовим соціальним стандартом $є$ прожитковий мінімум. Визначено також стандарти у copepi: доходів населення, житлово-комунального обслуговування, побутового обслуговування, соціально-культурного обслуговування, охорони здоров'я; освіти;

- соціальне страхування: пенсійне; медичне; на випадок безробіття; від нещасного випадку на виробництві й профресійного захворювання, що спричинили втрату працездатності; у зв'язку 3 тимчасовою втратою працездатності й витратами, зумовленими похованням;

- сощіальна допомога: малозабезпеченим сім'ям; сім'ям 3 дітьми; дітям-сиротам; матерямгероїням; інвалідам з дитинства та дітям-інвалідам; субсидії та компенсації; на догляд; на поховання; постраждалим внаслідок аварії на ЧАЕС; постраждалим учасникам Револющії Гідності та учасників АТO; особам, котрі не мають права на пенсію;

- соціальні послуги: догляд вдома, денний догляд; підтримане проживання; соціальна адаптація; соціальна інтеграція та реінтеграція; надання притулку; екстрене (кризове) втручання; консультування; соціальний супровід; представництво інтересів; посередництво (медіація); соціальна профрілактика; натуральна допомога; фрізичний супровід осіб з інвалідністю; переклад жестовою мовою; догляд та виховання дітей в умовах, наближених до сімейних; супровід під час інклюзивного навчання; інформування.

Відповідно до Закону України «Про державні соціальні стандарти та державні соціальні гарантії, державні соціальні гарантї - це встановлені законами мінімальні розміри оплати праці, доходів громадян, пенсійного забезпечення, соціальної допомоги, розміри інших видів соціальних виплат, встановлені законами та іншими нормативно-правовими актами, які забезпечують рівень життя не нижчий від прожиткового мінімуму [2].

Основні державні соціальні гарантії встановлюються законами з метою забезпечення конституційного права громадян на достатній життевий рівень.

Державні соціальні гарантії є обов'язковими для всіх державних органів, органів місцевого самоврядування, підприемств, установ і організацій незалежно від форми власності.

Органи місцевого самоврядування при розробці та реалізації місцевих соціально-економічних програм можуть передбачати додаткові соціальні гарантії за рахунок коштів місцевих бюджетів [2].

Законом України «Про державні соціальні стандарти та державні соціальні гарантії» визначено основні засади фінансового забезпечення надання державних соціальних гарантій.

Надання державних соціальних гарантій здійснюеться за рахунок бюджетів усіх рівнів, 
коштів підприемств, установ і організацій та соціальних фондів на засадах адресності та цільового використання.

Державні соціальні гарантії та державні соціальні стандарти і нормативи є основою для розрахунку видатків на соціальні цілі та формування на їх основі бюджетів усіх рівнів та соціальних форонів, міжбюджетних відносин, розробки загальнодержавних i місцевих програм економічного і сощіального розвитку.

Відповідно до Закону України «Про державні соціальні стандарти та державні соціальні гарантії, державні соиіальні стандарти - встановлені законами, іншими нормативно-правовими актами соціальні норми і нормативи або їх комплекс, на базі яких визначаються рівні основних державних сощіальних гарантій [2].

На основі соціальних стандартів визначаються розміри основних соціальних гарантій: мінімальних розмірів заробітної плати та пенсії за віком, інших видів соціальних виплат і допомоги.

Формування державних соціальних стандартів і нормативів здійснюеться за такими принципали:

- забезпечення визначених Конституцією України соціальних прав та державних соціальних гарантій достатнього життевого рівня для кожного

- законодавчого встановлення найважливіших державних сощіальних стандартів і нормативів;

- диференційованого за соціально-демографрічними ознаками підходу до визначення нормативів;

- наукової обгрунтованості норм споживання та забезпечення;

- соціального партнерства;

- гласності та громадського контролю при їх визначенні та застосуванні;

- урахування вимог норм міжнародних договорів України у сфрері сощіального захисту та трудових відносин.

Відповідно до Закону України «Основи законодавства України про загальнообов'язкове державне соціальне страхування», загальнообов'язкове державне соиіальне страхування - це система прав, обов'язків і гарантій, яка передбачає надання соціального захисту, що охоплює: матеріальне забезпечення громадян у випадку хвороби, повної, часткової або тимчасової втрати працездатності, втрати годувальника, безробіття 3 незалежних від них обставин, а також у старості й інших випадках, передбачених законом, за рахунок грошових фондів, що фоормуються внаслідок сплати страхових внесків власником або уповноваженим ним органом, громадянами, а також бюджетних та інших джерел, передбачених законодавством [3].

Страховиками є цільові страхові фоонди 3: пенсійного страхування; страхування у зв'язку 3 тимчасовою втратою працездатності, від нещасних випадків на виробництві та професійних захворювань, медичного страхування; страхування на випадок безробіття.

Соціальна дополога - це система заходів, спрямованих на повернення особи до активного життя та праці, відновлення соціального статусу і формування в особи якостей, установок щодо пристосування до умов нормальної життєдіяльності шляхом правового і матеріального захисту iii існування, підготовки до самообслуговування
3 формуванням здатності до пересування і спілкування, повсякденних життевих потреб тощо.

Відповідно до Закону України «Про соціальні послуги», соціальні послуги - це дії, спрямовані на профрілактику складних життевих обставин, подолання таких обставин або мінімізащію їх негативних наслідків для осіб/сімей, які в них перебувають [4].

Обсяг видатків зведеного бюджету на соціальний захист та соціальне забезпечення населення протягом 2016-2020 рр. зростав (від 258,3 млрд. грн. у 2016 році до 346,7 млрд. грн. у 2020 році) (рис. 1). Проте, частка видатків зведеного бюджету на сощіальний захист та соціальне забезпечення населення у загальних видатках зведеного бюджету протягом 2016-2020 рр. зменшувалась (i3 $30,9 \%$ у 2016 році, до $21,7 \%$ у 2020 році).

Також протягом 2016-2020 рр. зменшилась частка видатків зведеного бюджету на соціальний захист та соціальне забезпечення населення у ВВП (з 0,8\% у 2016 рощі до 8,3\% у 2020 рощі). Слід зазначити, що протягом досліджуваного періоду відбувалось зростання обсягу ВВП (3 2383,2 млрд. грн. у 2016 рощі до 4194,1 млрд. грн. у 2020 році), проте якщо у 2016 році ВВП зріс порівняно 3 попереднім роком на 20,4\%, у 2017 році - на 25,2\%, у 2018 році - на 19,3\%, у 2019 році - на $11,7 \%$, то у 2020 році - зростання ВВП відбулось лише на 5,5\%.

Динаміка видатків Зведеного бюджету України на сощіальний захист та соціальне забезпечення (за фрункціональною класифікацією видатків та кредитування бюджету) протягом 2016-2020 pp. наведена на рис. 2.

Найбільшу частку у видатках Зведеного бюджету України на соціальний захист та соціальне забезпечення (за фрункціональною класифікацією видатків та кредитування бюджету) займають видатки на соціальний захист пенсіонерів. Проте на тлі зменшення частки видатків Зведеного бюджету України на соціальний захист та соціальне забезпечення спостерігаємо також і зменшення частки видатків на соціальний захист пенсіонерів (з 17,7\% у 2016 рощі, до 13,3\% у 2020 році) попри зростання суми цих видатків 3 147,6 млрд. грн. у 2016 рощі, до 212,3 млрд. грн. у 2020 році. Видатки на соціальний захист пенсіонерів у 2020 рощі зросли на 11\% порівняно з 2019 роком, і на 43,8\% порівняно з 2016 роком.

Частка видатків на соціальний захист на випадок непрацездатності у видатках Зведеного бюджету України зменшилась $31,2 \%$ у 2016 році до $0,3 \%$ у 2020 році. Протягом 2017 - 2019 рр. відбувалось поступове зростання обсягів видатків на соціальний захист на випадок непрацездатності з 10,3 млрд. грн. у 2016 р. до 18,7 млрд. грн. у 2019 р. (на 24\% у 2017 р., на $25 \%$ у 2018 р. та на $16 \%$ у 2019 р. відповідно, порівняно з попереднім роком), а у 2020 році спостерігається різке зменшення цього показника на 78,4\% 3 18,7 млрд. грн. у 2019 р. до 4,0 млрд. грн. у 2020 р. (або на 14,7 млрд. грн.).

Частка видатків на соиіальний захист ветеранів війни та праці у видатках Зведеного бюджету України зменшилась з 0,8\% у 2016 рощі до $0,1 \%$ у 2020 році. Лише у 2018-2019 рр. відбувалось зростання обсягів видатків на соціальний захист ветеранів війни та праці порівняно 3 попередніми роками, а у 2020 році спостеріга- 


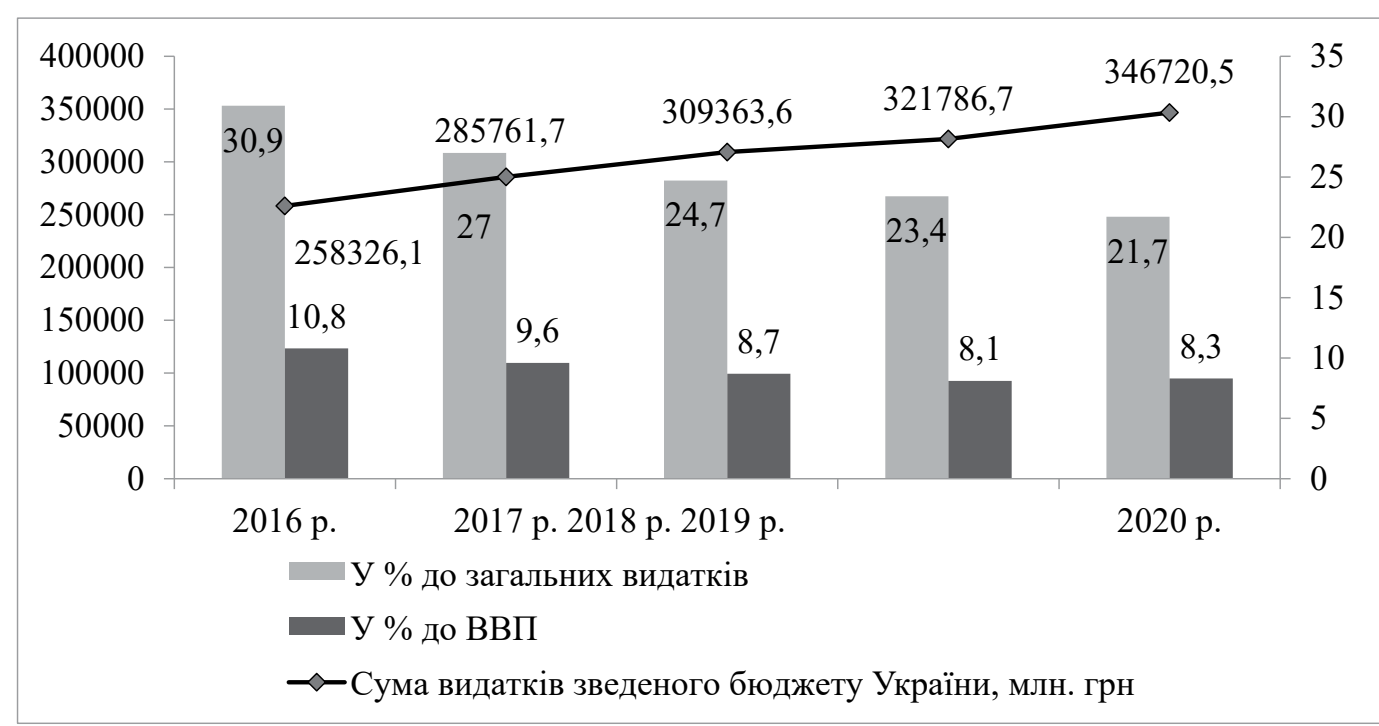

Рис. 1. Динаміка видатків Зведеного бюджету України на соціальний захист та соціальне забезпечення населення протягом 2016-2020 pp.

Джерело: побудовано авторами за даними [7]

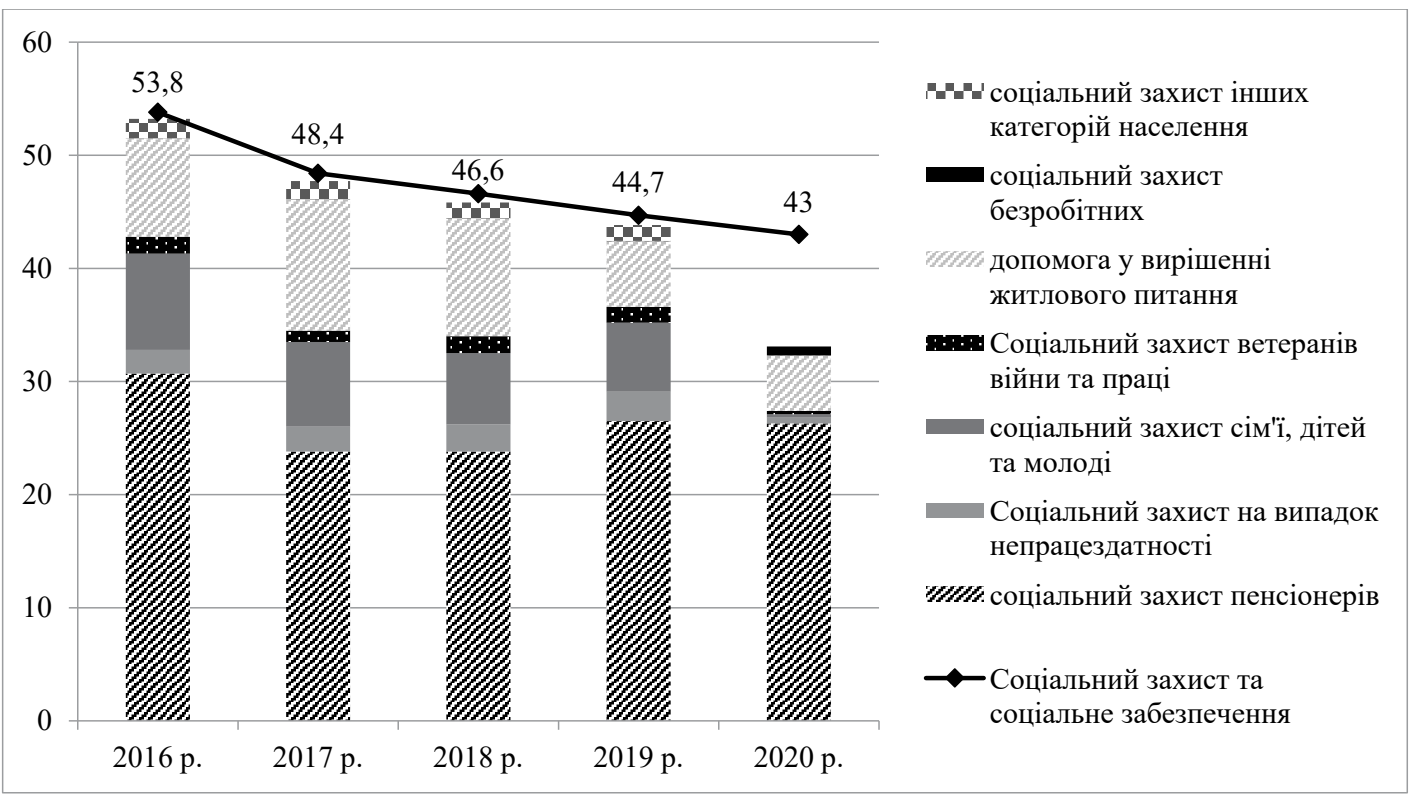

Рис. 2. Динаміка частки видатків Зведеного бюджету України на соціальний захист та соціальне забезпечення (за функціональною класифікаціею видатків та кредитування бюджету) протягом 2016-2020 рр., \%

Джерело: побудовано авторами за даними [7]

ється різке зменшення цього показника на 77,3\% з 9,9 млрд. грн. у 2019 р. до 2,2 млрд. грн. у 2020 р. (або на 7,7 млрд. грн.).

Частка видатків на соціальний захист сіл'ї, dimeй ma молодi у видатках Зведеного бюджету України зменшилась 3 4,9\% у 2016 році до $0,1 \%$ у 2020 році. Зростання обсягів видатків на соціальний захист сім'ї, дітей та молоді відбувалось лише у 2017 та 2019 роках (на 8,4\% та на 5,3\% відповідно, порівняно 3 попереднім роком), а у 2020 році спостерігається різке зменшення цього показника на 95,1\% з 44,1 млрд. грн. у 2019 р. до 2,2 млрд. грн. у 2020 р. (або на 41,9 млрд. грн.).

Частка видатків на соціальний захист безробimнux у видатках Зведеного бюджету України зросла 3 0,01\% у 2016 році до 0,4\% у 2020 році.
Протягом 2017-2019 рр. відбувалось зростання цього показника (на 14\% у 2017 р., на 40,4\% у 2018 р., на 24\% у 2019 р.), а у 2020 році спостерігаємо різке зростання обсягу видатків на соціальний захист безробітних у 36 разів. Певною мірою зростання цього показника у 2020 році пов'язане із збільшенням кількості безробітних, спричиненим хворобою COVID-19.

Частка видатків на допологу у вирішенні житлового питання у видатках Зведеного бюджету України, починаючи з 2018 року, зменшувалась, порівняно 3 попереднім періодом (з 5\% у 2016 р. до $2,5 \%$ у 2020 р.). 32019 р. спостерігаємо також зменшення обсягу видатків на допомогу у вирішенні житлового питання з 69,2 млрд. грн. у 2018 р. до 39,4 млрд. грн. у 2020 р. (або на 43\%). 
«Молодий вчений» • № 11 (99) • листопад, 2021 р.

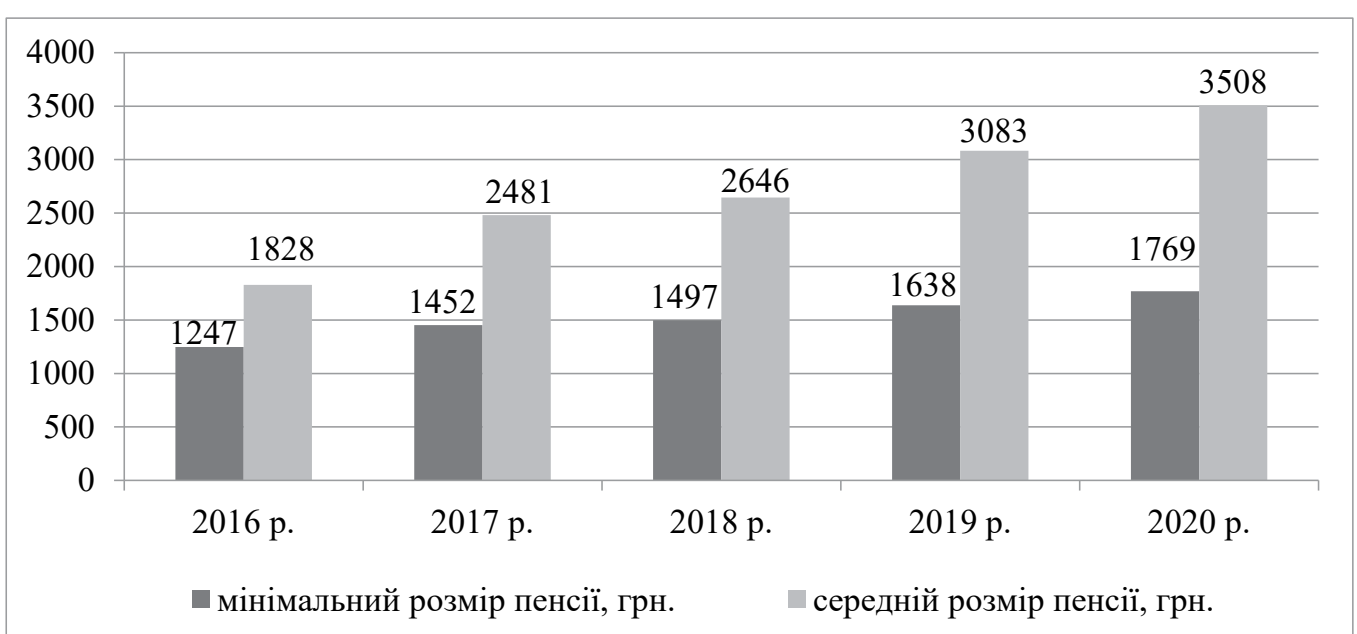

Рис. 3. Динаміка рівня пенсійного забезпечення протягом 2016-2020 pp.

Джерело: побудовано авторами за даними [9]

Частка видатків на соиіальний захист інших категорій населення у видатках Зведеного бюджету України протягом 2016-2019 рр. коливалась у межах $0,7 \%$, а у 2020 році спостерігаємо iii зростання до 4,6\%. Обсяг цього показника зростав порівняно з попереднім періодом, за винятком 2018 року (з 8,3 млрд. грн. у 2018 р. до 73,5 млрд. грн. у 2020 р.). У 2020 році відбулось різке зростання (у 7,2 рази) цього показника порівняно з 2019 роком.
Середній розмір пенсії по Україні на 01.01.2019 складав 2 645,66 грн, що на 6,7\% більше порівняно із показником на 01.01.2018, а станом на 01.01.2021 становив 3507,51 грн, що на $13,8 \%$ більше в порівняні до аналогічного періоду минулого року. При цьму таке зростання перевищує показник інфрлящії за цей період більше ніж удвічі (рис. 3).

Чисельність пенсіонерів, які отримують пенсію в розмірі менше ніж 2000 грн за 2020 рік

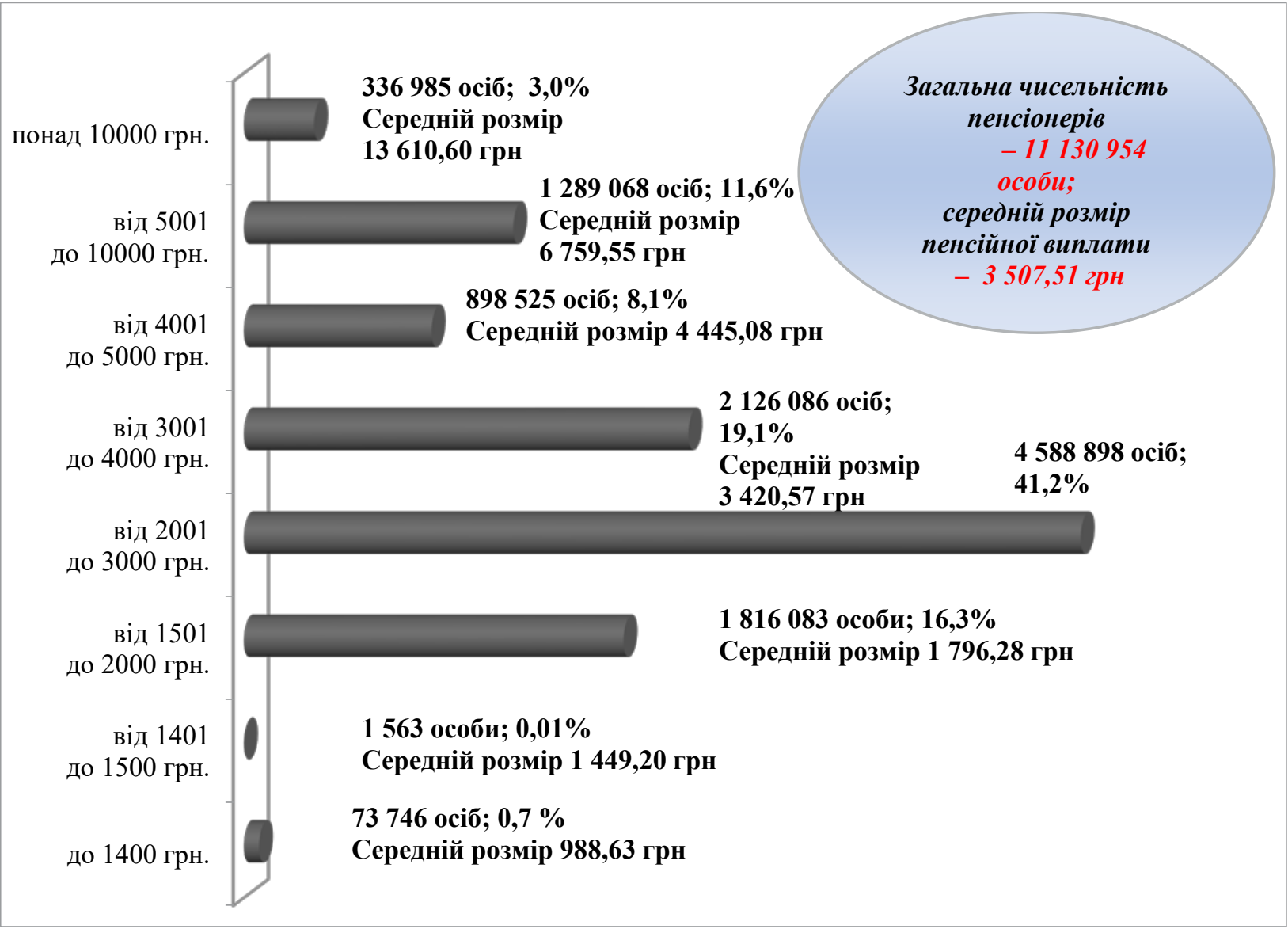

Рис. 4. Питома вага пенсіонерів за розмірами призначених місячних пенсій у загальній їх чисельності станом на 01.01.2021 
зменшилася з 4,0 млн осіб до 1,8 млн осіб, або на $53,1 \%$ (станом на 01 січня 2021 року). При цьому чисельність пенсіонерів в інших групах в розрізі суми пенсійних виплат зростає (рис. 4).

У квітні 2020 року відповідно до статті 37 Закону України від 23.09.1999 № 1105 «Про загальнообов'язкове державне соціальне страхування» та постанови Кабінету Міністрів України від 01.04.2020 № 249 «Про перерахування розміру щомісячних страхових виплат потерпілим від нещасного випадку на виробництві та продессійного захворювання, які спричинили втрату працездатності, та особам, які мають право на страхові виплати у разі смерті потерпілого» Фондом соціального страхування України здійснено перерахування сум щомісячних страхових виплат 205,2 тисячам потерпілих на виробництві та особам, які мають право на виплати в разі втрати годувальника на коефіціент 1,11 (рис. 5).

За результатами проведеного перерахунку розмір щомісячних страхових виплат збільшився в середньому на 376,4 грн, а для 89,1 тис. потерпілих 3 числа шахтарів та членів їхніх сімей на 514,2 гривні [8].

Законом України від 07.05.2020 № 587 внесено зміни до статті 24 Закону України від № 1105 «Про загальнообов'язкове державне сощіальне страхування», якими передбачено, що медичним працівникам, які перебувають у закладах охорони здоров'я, а також на самоізоляції під медичним наглядом у зв'язку з проведенням заходів, спрямованих на запобігання виникненню та поширенню коронавірусної хвороби (COVID-19), а також локалізацію та ліквідацію їі спалахів та епідемій, ви- плачується допомога по тимчасовій непрацездатності в розмірі 100\% середньої заробітної плати (доходу) незалежно від страхового стажу, іншим застрахованим особам у таких відпадках - 50\% середньої заробітної плати (доходу) [5].

Запроваджено нову соціальну виплату на час втрати заробітку у період карантину - допомогу на дітей до 10-річного віку для фрізичних осіб підприємщів, які обрали спрощену систему оподаткування та належать до першої і другої групи платників єдиного податку, не використовують найману працю і $є$ платниками единого внеску на загальнообов'язкове державне соціальне страхування (на дітей до 6 років - 1779 грн, від 6 до 10 років - 2218 гривень).

Така виплата здійснювалася 3 травня до 1 вересня та була поновлена на листопад - грудень 2020 року (постанова Кабінету Міністрів України від 22.04.2020 № 329, зі змінами).

На виконання Закону України «Про соціальну підтримку застрахованих осіб та суб'єктів господарювання на період здійснення обмежувальних протиепідемічних заходів, запроваджених 3 метою запобігання поширенню на території України гострої респіраторної хвороби COVID-19, спричиненої коронавірусом SARS-CoV-2» [6] у грудні 2020 року забезпечено виплати одноразової матеріальної допомоги застрахованим особам: фрізичним особам - підприемцям та працівникам підприемств, діяльність яких тимчасово зупинена внаслідок обмежувальних протиепідемічних заходів, - у розмірі 8000 грн (постанова Кабінету Міністрів України від 09.12.2020 № 1235, зі змінами).

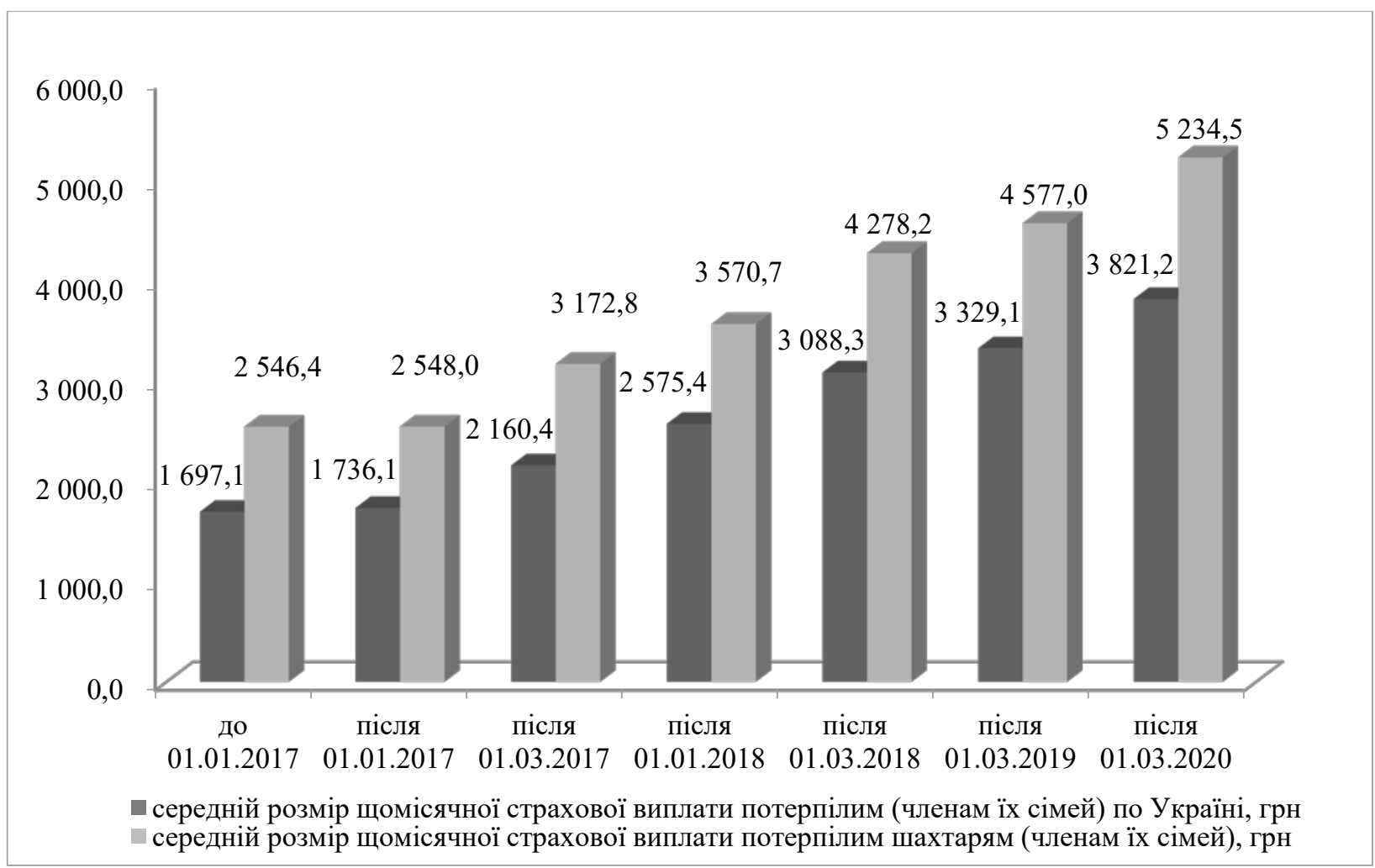

Рис. 5. Динаміка зростання середнього розміру щомісячних страхових виплат потерпілим (членам їх сімей) та потерпілим шахтарям (членам їх сімей) внаслідок проведених Фондом соціального страхування перерахунків 
Розмір допомоги для дітей, над якими встановлено опіку чи піклування

\begin{tabular}{|c|c|c|c|}
\hline Категорія & $\begin{array}{c}\text { Розмір допомоги } \\
\text { до змін, грн }\end{array}$ & $\begin{array}{c}\text { Розмір допомоги } \\
\text { з 01.01.2020, грн } \\
\end{array}$ & $\begin{array}{c}\text { Розмір допомоги } \\
\text { з 01.01.2021, грн }\end{array}$ \\
\hline Діти до 6 років & 3558 & 4447,5 & 4803 \\
\hline Діти від 6 до 18 років & 4436 & 5545 & 5988 \\
\hline Діти з інвалідністю до 6 років & 3558 & 6226,5 & 6724 \\
\hline Діти з інвалідністю від 6 до 18 років & 4436 & 7763 & 8383 \\
\hline
\end{tabular}

Джерело: [8]

Система соціальної допомоги в Україні має на меті підтримувати вразливі групи населення, зокрема малозабезпечені та одинокі сім'ї, які виховують дітей та перебувають в умовах, за яких не задовольняються у повній мірі їх соціальні потреби; жінок у період вагітності і пологів, при народженні та усиновленні дитини, а також дітей, які 3 тих чи інших причин позбавлені батьківського догляду і перебувають під опікою чи піклуванням, дітей та осіб з інвалідністю, дітей, один з батьків яких ухиляеться від сплати аліментів.

Державну допомогу станом на 1 січня 2021 року отримувало 3,7 млн отримувачів [8]. Із 1 січня 2020 року збільшилися розміри допомоги на дітей, над якими встановлено опіку чи піклування, - 32 до 2,5 розміру прожиткового мінімуму для дитини відповідного віку; на дітей 3 інвалідністю, над якими встановлено опіку чи піклування, - 32 до 3,5 розміру прожиткового мінімуму для дитини відповідного віку. Розмір допомоги для дітей, над якими встановлено опіку чи піклування, збільшено на 1245 грн - для дітей віком до 6 років; на 1552 грн - для дітей віком від 6 до 18 років; для дітей з інвалідністю на 3166 грн та 3947 грн відповідно (розміри у порівнянні із січнем 2020 та 2021 років).

Слід зазначити, що також посилено гарантії надання допомоги одиноким матерям та малозабезпеченим сім'ям із забезпеченням адресних засад її призначення з одночасним запровадженням механізмів, які стимулюють працездатних членів малозабезпечених сімей до самозабезпечення 3 метою виведення їх зі стану нужденності (постанова Кабінету Міністрів України від
22.07.2020 № 632 «Деякі питання виплати державної соціальної допомоги»).

Зазначені зміни відбувалися 3 одночасним збільшенням рівня забезпечення прожиткового мінімум для дітей з 85 до $130 \%$ відповідного прожиткового мінімуму і для працездатних осіб з 21 до 25\% прожиткового мінімуму, що дозволило комплексно підійти до питання підтримки сімей 3 низькими доходами.

Висновки і пропозиції. Сьогодні актуальним та нагальним є зміна стратегічних пріоритетів системи соціального захисту та формування нових актуальних стратегічних цілей. Протягом 30 років незалежності в Україні не було сформовано системної програми реформ у сфері сощіальної підтримки різних категорій громадян і сімей. Украй важливими $є$ цілі, досягнення яких дозволить оновити та оптимізувати систему соціального захисту України відповідно до сучасних викликів:

1. Трансорормація стратегії системи соціального захисту - перехід до створення можливостей замість долання наслідків. Пріоритетом має бути не лише соціальний захист населення, а й активна політика, спрямована на зниження рівня безробіття та збільшення частки заробітної плати у структурі доходів населення.

2. Удосконалення нормативно-правової бази, що регулюе загальні питання соціального захисту. Пріоритетом оновлення законодавства має стати редормування системи пільг та інших видів соціальних виплат, її уніфікація та посилення адресної державної соціальної допомоги.

Ці заходи, на нашу думку, сприятимуть підвищенню едективності системи соціального захисту.

\section{Список літератури:}

1. Конституція України : Закон України від 28.06.1996 № 254к/96-BP. URL: https://zakon.rada.gov.ua/laws/ show/254\%D0\%BA/96-\%D0\%B2\%D1\%80\#top

2. Закон України «Про державні соціальні стандарти та державні соціальні гарантії» від 5 жовтня 2000 року № 2017-III. URL: https://zakon.rada.gov.ua/laws/show/2017-14\#top

3. Закон України «Основи законодавства України про загальнообов’язкове державне соціальне страхування» від 14 січня 1998 року № 16/98-BP. URL: https://zakon.rada.gov.ua/laws/show/16/98-\%D0\%B2\%D1\%80\#Text

4. Закон України «Про соціальні послуги» від 17 січня 2019 року № 2671-VI. URL: https://zakon.rada.gov.ua/ laws/show/2671-19\#Text

5. Закон України «Про внесення змін до деяких законодавчих актів України з метою підвищення спроможності системи охорони здоров'я України протидіяти поширенню коронавірусної хвороби (COVID-19)» від 07.05.2020 № 587-IX. URL: https://zakon.rada.gov.ua/laws/show/587-20\#Text

6. Закон України «Про соціальну підтримку застрахованих осіб та суб’ектів господарювання на період здійснення обмежувальних протиепідемічних заходів, запроваджених з метою запобігання поширенню на території України гострої респіраторної хвороби COVID-19, спричиненої коронавірусом SARS-CoV-2» від 09.04.2021 № 1071-IX. URL: https://zakon.rada.gov.ua/laws/show/1071-20\#Text

7. Державна казначейська служба України. Офіційний сайт. URL: https://www.treasury.gov.ua/ua/file-storage/ vikonannya-derzhavnogo-byudzhetu

8. Міністерство соціальної політики України. Офіційний сайт. URL: https://www.msp.gov.ua/

9. Пенсійний фонд України. Інформаційна сторінка вебпорталу. URL: https://www.pfu.gov.ua/

10. Туленков М.В. Соціальний захист у соціологічному вимірі : монографія. Київ : ІПК ДСЗУ, 2011.168 с. 


\section{References:}

1. Constitution of Ukraine. Law of Ukraine № 254к/96-BP (1996, June 28). Retrieved from: https://zakon.rada.gov.ua/ laws/show/254\%D0\%BA/96-\%D0\%B2\%D1\%80\#top (in Ukrainian)

2. Law of Ukraine «On State Social Standards and State Social Guarantees»»" № 2017-III (200, October 5). Retrieved from: https://zakon.rada.gov.ua/lawsshow/2017-14\#top (in Ukrainian)

3. Law of Ukraine «Fundamentals of the legislation of Ukraine on compulsory state social insurance» № 16/98-BP (1998, January 14). Retrieved from: https://zakon.rada.gov.ua/laws/show/16/98-\%D0\%B2\%D1\%80\#Text (in Ukrainian)

4. Law of Ukraine «On Social Services» № 2671-VII (2019, January 17). Retrieved from: https://zakon.rada.gov.ua/ laws/show/2671-19\#Text (in Ukrainian)

5. Law of Ukraine «On Amendments to Certain Legislative Acts of Ukraine in order to increase the capacity of the health care system of Ukraine to counteract the spread of coronavirus disease (COVID-19)» від 07.05.2020 №587-IX (2020, May 07). Retrieved from: https://zakon.rada.gov.ua/laws/show/587-20\#Text (in Ukrainian)

6. Law of Ukraine «On social support of insured persons and business entities for the period of implementation of restrictive anti-epidemic measures introduced to prevent the spread of acute respiratory disease COVID-19 caused by coronavirus SARS-CoV-2» on the territory of Ukraine № 1071-IX(2021, April09). Retrieved from: https://zakon.rada.gov.ua/laws/show/1071-20\#Text (in Ukrainian)

7. Derzhavna kaznacheiska sluzhba Ukrainy. Ofitsiinyi sait [State Treasury Service of Ukraine]. Retrieved from: https://www.treasury.gov.ua/ua/file-storage/vikonannya-derzhavnogo-byudzhetu (in Ukrainian)

8. Ministerstvo sotsialnoi polityky Ukrainy. Ofitsiinyi sait [Ministry of Social Policy of Ukraine]. Retrieved from: https://www.msp.gov.ua/ (in Ukrainian)

9. Pensiinyi fond Ukrainy. Informatsiina storinka vebportalu [Pension Fund of Ukraine]. Retrieved from: https://www.pfu.gov.ua/ (in Ukrainian)

10. Tulenkov M.V. (2011) Sotsialnyi zakhyst u sotsiolohichnomu vymiri: monohrafiia [Social protection in the sociological dimension]. Kyiv: IPK DSZU. (in Ukrainian) 